\title{
On The Role of Modern Doctrines on Human Rights (International Legal Examination)
}

\author{
Adel Abdullin, Ainur Gilmullin, Lenara Klimovskaya, Vagip Abdrashitov
}

\begin{abstract}
The modern doctrines on human rights, which are proposed to be considered in the context of their implementation in international legal practice, are the subject of theoretical and legal analysis in the paper. It is noted that human rights have come a long way in their formation, design and subsequent genesis, and they have finally formed by the end of the last century, and it seems that now all the necessary conditions have been created for their philosophical, legal, axiological analysis and relevant rational consideration of human rights.

The advantages of international law in the field of human rights are listed; namely, it is noted that international human rights standards are universal in nature and are binding based on which states are obliged to ensure a minimum standard of those rights and freedoms that are enshrined in international acts,

There are listed in the paper advantages of international legal regulation regarding human rights and freedoms, such as the supranational, mandatory and imperative nature of international acts; guarantees of protection and the possibility of restoring violated rights and freedoms of citizens; a man-centred approach in resolving disputes and conflicts arising in international practice. The role of international bodies such as the International Criminal Court, the International Tribunal for the Law of the Sea, the Court of the European Union, the European Court of Human Rights, the International Tribunals for Rwanda and the Former Yugoslavia, and the Special Court for Sierra Leone, is emphasized.
\end{abstract}

Particular attention is paid to the principle of presumption of innocence, which has fundamental and quintessential characteristics in the field of human rights.

Keywords: doctrine, human rights, international law, the principle of the presumption of innocence, priorities, rights and freedoms, judicial practice.

\section{INTRODUCTION}

As is known, human rights in the broadest sense represent a concept that is reflected in the socio-legal category [1] expressed in a system of deeply interrelated norms generally characterizing the general legal status of an individual in its various relations and in relation to the state, its capabilities, goals, claims and main priorities in certain areas of life, including human priorities in areas such as economic, social, political and cultural spheres. Meanwhile, it should be noted right away that human rights have come a long way in their historical formation, design and subsequent genesis, having finally formed by the end of the last century. Today, it's important to emphasize that there are all necessary conditions for their philosophical and legal analysis and deeper research, because according to G.V.F. Hegel "those laws are reasonable

Revised Manuscript Received on November 08, 2019.

* Correspondence Author

Adel Abdullin, Kazan Federal University

Ainur Gilmullin, Kazan Federal University

Vagip Abdrashitov, Volgograd State University, Institute of law
Lenara Klimovskaya, Kazan Federal University

that correspond to the nature of man, the concept of man, and freedom" [2].

At the same time, international law related to human rights is a synthesis of generally binding legal principles and norms that govern mainly relations between peoples, states and international organizations, determining their mutual rights and obligations. It is noteworthy that even at the very early stages of the development of society and its forms of interaction, primitive tribes and peoples actively supported intertribal, interclannish and international relations among themselves. At that time, these relations were regulated exclusively by customs and traditions, which were a kind of archetype of the first legal provisions having international nature that arose only with the development of statehood in most nations of the world. So, back in $1286 \mathrm{BC}$, the first formal treaty was concluded, the parties of which were Pharaoh Ramses II and the Hittite king Hattusili III. The treaty contained legal norms indicating its mandatory compliance [3].

As noted, international law as a special legal system is the product of just collective international interaction in the process of cooperation and struggle of various states in achieving their goals. Of course, it differs from all national legal systems, because in international relations there is no supranational body that would coordinate or enforce compliance with certain obligations, since everything in international law is based solely on good faith and voluntariness, including the principle of "Pacta sunt servanda " (Lat.): treaties must be respected. A feature of international law is its special conciliatory nature, i.e. actors (in the international arena) themselves form, develop, coordinate and control the collective rules of their behaviour, which fully applies to the field of human rights [4]. So, in 1968 the USSR signed, and in 1973 ratified the International Covenant on Civil and Political Rights, as well as other acts on human rights. When signing and ratifying them, the USSR ignored Art. 5 of the Covenant, which states: "Nothing in the present Covenant may be interpreted as implying for any State, any group or any person has the right to engage in any activity or to perform any whatsoever action aimed at the destruction of any rights or freedoms recognized in this Covenant, or at their restriction to a greater extent than provided for in this Covenant." The Universal Declaration of Human Rights and other international human rights standards are universal in nature and have fundamental universally binding force [5]. Proceeding from this, it follows that national states are obliged to guarantee compliance with the basic provisions and principles on human rights and freedoms contained in international documents, and if the laws of national states do not comply with the provisions of international documents, this will be considered legitimate only exclusively in areas where 
human rights and freedoms are expanded. This is due to that, according to the dominant natural-legal type of legal understanding of human rights and freedoms in international law, are not the creation and talent of the state and government, but are natural and inalienable by virtue of nature, and, moreover, enshrined in the basic laws of national states. Consequently, nation states have expressed their consent to their observance, implementation and realisation in their legal systems [6].

So, for example, paragraph 4, Article 15 of the Constitution of the Russian Federation states that universally recognized principles and norms of international law and international treaties of the Russian Federation are an integral part of its legal system. If an international treaty concluded by the Russian Federation establishes other rules than provided for by its domestic law, then the rules of the international treaty are applied. As is known, those treaties have been actively developed back in the second half of the 20th century, when jus cogens norms became especially active. This fully applies to human rights acts, including the principle of presumption of innocence.

We recall that in accordance with Article 52 of the Vienna Convention on the Law of Treaties (1969), the term "jus cogen" in the modern doctrine of international law refers to the norm of general international law adopted and recognized by the international community of states as a whole, deviation from which is unacceptable. Moreover, it can be changed only by a subsequent rule of general international law of the same nature. Thus, the norms of "jus cogens" are the norms of general international law, i.e. its basic principles specified in the UN Charter. Their content is reflected in the Declaration on the Principles of International Law Relating to Friendly Relations and Cooperation between States in accordance with the UN Charter of October 24, 1970, which also relates to the need to respect, ensure and protect human rights and freedoms.

\section{METHODS}

When conducting the study, we used general scientific and special scientific methods of cognition, including system-structural, problem-theoretical, formal-legal, historical-legal, comparative-legal, logical, etc.

\section{RESULTS AND DISCUSSION}

In order to protect human rights in modern international practice, there are a considerable number of both regulatory and declarative legal acts, international treaties (agreements), and political and legal institutions (bodies) aimed at ensuring the protection and restoration of violated human rights and freedoms. These include UN International Court of Justice, International Criminal Court, EU Court of Justice, European Court of Human Rights, Tribunals for Rwanda and the Former Yugoslavia, Special Court for Sierra Leone, International Criminal Court, International Tribunal for the Law of the Sea, etc.

Of particular concern today are the possibilities of prompt and maximum effective prevention of massive violations of human rights and freedoms in the national and international space, punishment of perpetrators, as well as the resolution of disputes and conflicts arising in the field of interstate and intergovernmental relations and the classification of the resolution of these disputes as supranational bodies (courts). In this regard, issues related to the trust and competence of these bodies come first.

According to half three, article fifty six of the Constitution of the Russian Federation, human rights and freedoms enshrined in articles fifteen, 21, 23, forty six and forty nine (presumption of innocence) can't be subject to restriction even in a very state of emergency. These rules produce real opportunities for the protection of rights and freedoms profaned as a results of judicial errors. Associate in Nursing unlawful court call can't be considered a good act and should be corrected while not fail. So, the decree $\mathrm{N}$ ten dated October twenty five, 1996 by plenum of the Supreme Court of the Russian Federation emphasized: in accordance with Art. nine of the International Covenant on Civil and Political Rights (which norms, by virtue of half four, Art.15 of the Constitution of the Russian Federation is Associate in Nursing integral a part of the system of the Russian Federation and have dominance over its domestic legislation ), everybody United Nations agency is empty his/her liberty as a results of arrest or detention in custody has the correct to listen to his case in court [9] in order that this court will forthwith issue Associate in Nursing order relating to the quality of his/her detention and to order his/her unleash if the detention is unlawful [10].

Thus, the Constitutional Court of the Russian Federation increasingly implements in its decisions the ideas of the Convention and the International Covenant on Civil and Political Rights, directly refers to articles and provisions of specific international legal acts, and in recent years directly to relevant decisions of the European Court of Human Rights (hereinafter referred to as the Court). The case of the Constitutional Court of the Russian Federation on the complaint of V.I. Maslov dated June 27, 2000, in which the Constitutional Court used the interpretation of Article 6 of the European Convention, presented in a number of decisions of the European Court, is an additional confirmation of this. Recall that article 6 of the Convention, guaranteeing the right to a fair trial, has an important coordinating position in an open democratic secular society. Its paragraph 1 is not subject to restrictive interpretation, and the right to an effective remedy directly connected with it and guaranteed in article 13 , also has a related and close meaning to the above concept.

It seems that based on the interpretation of the provisions of Article 6 it follows that (although not explicitly stated, the Court refers to this fact in its numerous decisions) both the principle of competition, the principle of equality of arms, as well as such rights and fundamental provisions as: the right to independent and an impartial court, which is created impartially by law; the right to a trial by any court within a reasonable time; the right to a public (open) nature of the proceedings, as well as such legal principles as the principle of the presumption of innocence and those procedural guarantees, without which the trial cannot be considered fair [11].

\section{SUMMARY}

Thus, we can conclude that Article 6 of the Convention, which contains an imperative on the need to comply with the principles of adversarial proceedings, equality of arms and the presumption of 
innocence, i.e. indicates that any person should be provided with real, adequate and not prohibited by law means and methods of procedural protection [12], giving guarantees for an objective and impartial trial, in particular, to state objections and arguments; ask questions to a person who is a witness in the case and opposed [13]; provide any evidence and documents in the framework of the case, etc.

As the Supreme Arbitration Court of the Russian Federation rightly notes in its information letter adopted on December 20, 1999, No. S1-7 / SMP-1341, "The Russian judicial mechanisms for monitoring the observance of property rights of participants in economic turnover in the Russian Federation received support in the form of international judicial control. This means that the competence of arbitration courts to consider property disputes and the competence of the European Court to consider complaints of violation of property rights are interrelated. The connection is based on the need to solve the single task of international and domestic legal proceedings: the protection of the property rights of individuals with proper protection of public order, which follows from Article 6 of the European Convention and Article 1 of Protocol 1 to this Convention (1952)" [14]. This seems to finally solve the issue of both the jurisdiction of the court itself [15] and the views of individual countries on this complex problem [16].

Thus, based on the content of articles 6 and 13 which deal with the scope and definition of civil rights and obligations $[17,24]$, as well as with the availability of effective legal remedies, accordingly, it can be reasonably argued that pointing to them is the main evidence of complete and the thorough practical implementation of the provisions contained in the presumption of innocence, namely, paragraph 2 of Article 6, where the main emphasis is placed on criminal proceedings. This concretization (and according to the statistics of the Court, the provisions of Articles 6 and 13 are found in every second case) indicates only one thing: national courts should more carefully and consistently examine their legislation and the case-law of the European Court of Human Rights. The reason lies in the fact that the numerous errors of judges that the Court has to correct are primarily based on violations of their own national law, and only then go against the practice of the European Court of Human Rights.

It seems that the provisions of presumption of innocence [18, $22,23]$ directly related to the burden of proof for the prosecutor should be used more often by both national and international judicial bodies. This circumstance leads to a completely logical conclusion worthy of attention in the current situation: the European Court should not only more often refer to the provision of Article 6, $\S 2$ (i.e., presumption of innocence) explaining the meaning and content of the interpreted concept, but also pay attention of national courts on their own precedents, make appropriate proposals under Art.1 of the European Convention on Human Rights on the modernization of domestic judicial practice and changing their own views, ideas and stereotypes, and sometimes fixations regarding such an effective remedy for the rights and freedoms of a person as the principle of presumption of innocence.

Special mention should be made of the cases of the Court in which, with respect to Article 6 of the Convention on Human Rights, the judges had a special (individual) opinion, which seemed to be a significant help in the formation of ratio decidendi (motivations) for the presentation of the facts and circumstances of the case. We would not want to omit the fact that the European Court should already have created casebooks $[19,25]$ on certain categories of cases in order to increase the optimization and efficiency of its work.

All of the above would inevitably affect the expansion of judicial practice related to the application of international norms, which it has become commonplace in courts of all types and levels - in the systems of arbitration courts and courts of general jurisdiction, the Supreme and Constitutional Courts of the Russian Federation, and this practice is less common both in the authorized (constitutional), and in justice courts of the constituent entities of the Russian Federation.

\section{CONCLUSIONS}

It is worth noting that the role of international law itself has gradually changed as a whole: it serves not only as a traditional link in the relations of states in the international arena but also has become the basis for creating a common legal field, a common legal regime (economic, financial, informational, customs, digital, educational, etc.) within the territorial boundaries of states, up to the complete unification of legal norms. The instruments of this process are international treaties (agreements), international structures (organizations, commonwealths, and communities), unions, associations and union states.

According to the legal doctrine, international law is a set of general legal principles and regulations, on the basis of which the regulation of relations between states, intergovernmental organizations and other public entities takes place. In the near future, it will become that international law indeed (in the sense of relations arising between peoples), which in the literal sense of the word will become a tool with which people will build their relations and satisfy their daily needs. Social practice shows that the modern world order needs to be included in the international legal space not only of states but also of non-state entities and ordinary individuals. So, the representative of Russian scientific thought F.F. Martens stated that international law regulates not only relations between states, but also directly the relations between people. Thus, we can conclude that, based on the nomenclature of modern international practice, there is every reason to conclude that international law of the XXI century is a human right where his or her rights and freedoms will not only be declared and at a high level, but also be properly protected both in civilized Europe and throughout the world.

\section{REFERENCES}

1. Ebzeev B.S. Constitution. Democracy. Human rights. - Moscow Cherkassk, 1992. P.120-121.

2. Hegel G.V.F. The philosophy of law. - M., 1990. P.385

3. History of the Ancient World. Textbook and workshop for academic undergraduate // https://books.google.ru.

4. Boldyreva O. M. Protection of human rights in the history of international law // Bulletin of the Prikamsky Social Institute.2018. No. 1 (79). P. 14-20.

5. Brown R.E. The history of American Justice. - N.Y.; Boston, 2001. P. 127.

6. Gilmullin A. R. Sobre los elementos estructurales de una doctrina legal de presunción de inocencia / Ainur Gilmullin, Alexander Pogodin, Vagip Abdrashitov // Revista Dilemas Contemporáneos: Educación, Política y Valores. - Año: VI. Número: Edición Especial. Artículo no.:17. - Diciembre 2018. - P. $1-12$ 
7. Allen D. Russian tomorrow: Justice and Corts. - L.; Roma, 1999. - P. 38.

8. Triber W. L. Methodology and Criteria in Due Process. - N. Y., 1978. - P. 153.

9. Maitland F. W. The Constitutional history of England. - P. 314.

10. Resolution by the Plenum of the Supreme Court of the Russian Federation dd. October 25, 1996 No. 10 // ppvs.rf / 1996 / postanovlenie-plenuma-vs-rf / N10-ot-25.10.1996.html.

11. Vereshchetin V.S. Some aspects of the correlation between international and national law in the practice of the UN International Court of Justice // Russian Journal of Law. - 2007. - N 3. - P. 19-26.

12. Ferrazzini vs. Italy. European Court of Human Rights. $2001 / /$ https://www.echr.coe.int/Documents/FS_Taxation_RUS.pdf.

13. Schenk vs Switzerland. (Shenk vs. Switzerland. The judgment of the European Court of Human Rights of July 12, 1988. Ser. A N.140. 